\title{
Correction to: Successful limb salvage beyond the golden time following blunt traumatic open complete transection of the femoral artery and vein in a patient with cardiac arrest: a case report
}

Hoshi Himura, Kenichiro Uchida* ${ }^{*}$, Masahiro Miyashita and Yasumitsu Mizobata

\section{Correction to: Surg Case Rep (2021) 7: 177}

https://doi.org/10.1186/s40792-021-01264-x

Following publication of the original article [1], the authors identified an error in the family name of the third author Masahiro Miyashita.

The incorrect author name is: Masahiro Hiyashita.

The correct author names is: Masahiro Miyashita.

The author group has been updated above and the original article has been corrected in the author list and Authors' contributions section

Published online: 27 August 2021
Reference

1. Himura H, Uchida K, Miyashita M, Mizobata Y. Successful limb salvage beyond the golden time following blunt traumatic open complete transection of the femoral artery and vein in a patient with cardiac arrest: a case report. Surg Case Rep. 2021;7:177.

\section{Publisher's Note}

Springer Nature remains neutral with regard to jurisdictional claims in published maps and institutional affiliations. original author(s) and the source, provide a link to the Creative Commons licence, and indicate if changes were made. The images or other third party material in this article are included in the article's Creative Commons licence, unless indicated otherwise in a credit line to the material. If material is not included in the article's Creative Commons licence and your intended use is not permitted by statutory regulation or exceeds the permitted use, you will need to obtain permission directly from the copyright holder. To view a copy of this licence, visit http://creativecommons.org/licenses/by/4.0/. 